\title{
Health and energy chiefs sail through Senate
}

Matthew Davis and Irwin Goodwin, Washington The two cabinet secretaries who will oversee most US science in the new Bush administration sought confirmation from the Senate last week.

But as Tommy Thompson, the health secretary, and Spencer Abraham, the energy secretary, sailed through their confirmation hearings, little was revealed of their plans for US research. Abraham was duly confirmed on Saturday, with Thompson expected to follow early this week.

Although opposed to abortion, as governor of Wisconsin Thompson was a forceful advocate for human embryonic stem-cell research. He publicly lauded a scientist in the state who pioneered a technique for extracting stem cells from embryos, and stood up to anti-abortion groups opposed to the work.

But as President Bush's new Secretary of Health and Human Services, one of Thompson's first tasks could be to stop efforts by the National Institutes of Health (NIH) to provide federal funding to explore the therapeutic potential of stem cells. His department includes the NIH, and he will pay a key role in Bush's selection of its next director.

"It's hard for me to see how he can do a total about face and condemn this research as immoral when he is on record as having applauded this advance," says Paul Berg, a molecular biologist at Stanford University who heads the public policy committee at the American Society for Cell Biology.

But with no one seeking to upset his popular nomination, none of the senators asked Thompson for his views on statements from the Bush presidential campaign that the new administration would end the NIH's support of stem-cell research. And asked afterwards by a reporter whether he would be as supportive of stem-cell research

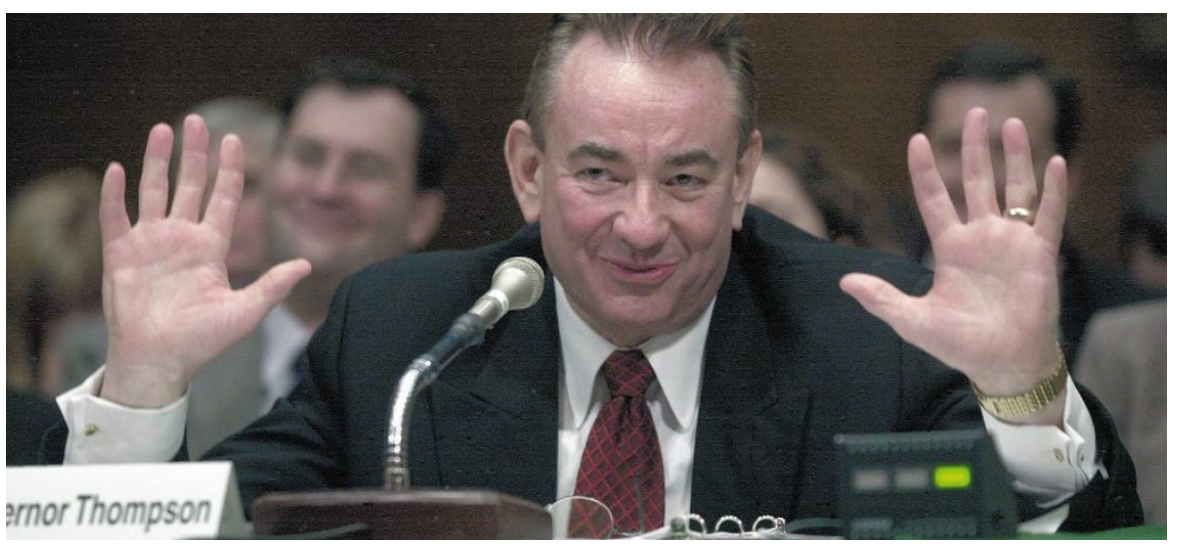

Hands off: health secretary Tommy Thompson refuses to be drawn on stem-cell research.

in Washington as he had been in Wisconsin, he refused to answer.

Proponents of stem-cell research were relieved the contentious issue was kept out of the limelight. They feared that putting Thompson on the spot would have forced him publicly to endorse the Bush campaign position. But the powerful anti-abortion lobby believes that Bush will still end the NIH initiative.

Ironically, the NIH's plan to allow stemcell research would depend on James Thomson of the University of Wisconsin at Madison to provide cell lines. Thompson described Thomson in his 1999 State of the State address as one of the "bold pioneers who are leading Wisconsin into the next millennium".

Sources in Wisconsin say that Thompson is quite knowledgeable about stem-cell research and could play a pivotal role in any internal administration debate.

The nomination of former senator Spencer Abraham as energy secretary raised some eyebrows because he had twice sponsored legislation to abolish the department he will now lead.

But Senator Jeff Bingaman (Democrat, New Mexico), who chaired the confirmation hearing, said that Abraham "has since seen the light and come to understand how much the department does for our energy security, our national security, our economy and our scientific and technological prowess".

Nuclear weapons labs get one-third of the department's \$19 billion budget, and the Office of Science, which supports nonweapons research, spends another $\$ 3$ billion of it. Last year, Abraham sponsored a bill to raise Department of Energy funds for science.

"The science and technology programmes at the department have been widely praised and justly so," Abraham told the hearing.

Concern has been expressed about Abraham's lack of any obvious qualification for the job. But Michael Lubell, a physicist at City University of New York and lobbyist at the American Physical Society, says Abraham is a "political pragmatist" who will probably take advice on science from Michigan congressman Vernon Ehlers, a former physicist.

\section{Canadian minister keeps researchers guessing}

\section{David Spurgeon, Montreal}

Canadian scientists are watching closely to see whether the new industry minister in the Liberal government, which was re-elected last November, will continue with the pro-science policies of recent years.

In the new government, Brian Tobin, the politically ambitious former premier of Newfoundland, replaces John Manley, who as industry minister was in charge of the nation's science and technology policy.

Under Manley's influence, science budgets increased and national networks such as the Canada Foundation for Innovation and the Canadian Institutes for Health Research were set up (see Nature 405, 722; 2000), raising morale among researchers.

But Tobin, who is perhaps best known for encouraging the Canadian coastguard to fire on Spanish fishing boats in a 1995 dispute known as the 'turbot war', is seen as an aggressive politician and an unknown quantity on research issues.

John de la Mothe, a science-policy expert at the University of Ottowa, is concerned that Tobin's confrontational approach might damage some of Manley's achievements, citing a "difference of style between the two".

But Ron Freedman, an official at The Impact Group, a consultancy firm specializing in science and technology, says: "Tobin was premier of Newfoundland, and a large part of their development strategy was

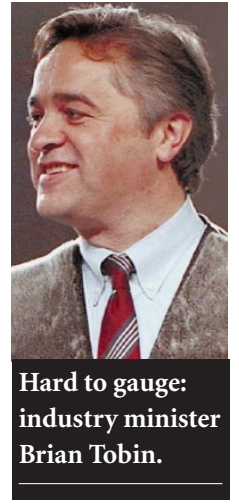

based around the new economy companies." Freedman adds that the new minister is "probably well aware of the issues" and will "pick up very quickly" on the government's existing research strategy.

John Reid, president of the Canadian Advanced Technology Association, says: “Tobin's made it quite clear that he respects what Manley has done and eventually is going to carry that forward." 